\title{
MIXED-MODE OFFICE BUILDINGS: ENERGY SAVINGS AND ILLUMINANCE LEVELS IN A HIGH- ALTITUDE TROPICAL CLIMATE
}

EDIFÍCIOS DE ESCRITÓRIOS DE MODO MISTO: ECONOMIA DE ENERGIA E NÍVEIS ADEQUADOS DE ILUMINÂNCIA EM UM CLIMA TROPICAL DE ALTITUDE

\author{
Rosilene Regolão Brugnera ${ }^{1}$ \\ Universidade de São Paulo, Instituto de Arquitetura e Urbanismo (IAU-USP), São Carlos, SP, Brasil, rosileneregolao@gmail.com \\ Caroline Antonelli Santesso ${ }^{2}$ \\ Centro Universitário da Fundação de Ensino Octávio Bastos, São João da Boa Vista, SP, Brasil, caroline.santesso@gmail.com \\ Karin Maria Soares Chvatal ${ }^{3}$ \\ Universidade de São Paulo, Instituto de Arquitetura e Urbanismo (IAU-USP), São Carlos, SP, Brasil, karin@sc.usp.br
}

\begin{abstract}
Mixed-mode buildings (MM), which use both natural ventilation and mechanical cooling to provide thermal comfort and energy savings, have a high potential in climates where it is favorable to use natural ventilation (e.g., Brazil). In these buildings, operable windows are the source of natural ventilation, lighting and heat gains, and their characteristics can influence energy consumption. This work aims to evaluate the energy and luminous performance of mixed-mode office buildings with operable windows in a highaltitude tropical climate in Brazil. The performance is evaluated concerning energy savings, air-conditioning operation hours, the period of use of natural ventilation and balance between energy demand and illuminance levels. It is considered variations in envelope parameters (window-to-wall ratio and solar orientation). The method is composed of computer simulations on Daysim and EnergyPlus programs. The results showed that the mixed-mode strategy has great potential to reduce air-conditioning energy consumption. The most significant reductions occurred with larger WWRs, reaching $39.4 \%$ of energy savings (north facade, WWR $=80 \%$ ). Nevertheless, while the larger WWR provided more natural ventilation availability, it increased the discomfort by high illuminance, which reached about $90 \%$ of the office's area. Therefore, when the mixed-mode system was used, the cases with a better balance between adequate illuminance levels and low energy consumption were the south facade with all WWRs and the east and west facades with WWR of $30 \%$. It is important to emphasize that the adoption of these solutions depends on the building's design requirements.
\end{abstract}

Keywords: Mixed-mode buildings. Hybrid ventilation. Energy consumption. Illuminance levels. High-altitude tropical climate.

\section{Resumo}

Edifícios de modo misto (MM), os quais usam ventilação natural e resfriamento mecânico para proporcionar conforto térmico e economia de energia, tem um grande potencial em climas onde o uso da ventilação natural é favorável (ex. Brasil). Nesses edifícios, as janelas operáveis são fontes tanto de ventilação natural quanto iluminação e ganhos internos, e suas características podem influenciar no consumo de energia. Este trabalho tem como objetivo avaliar o desempenho energético e luminoso de edifícios de modo-misto com janelas operáveis em um clima tropical de altitude no Brasil. Considerando variações nos parâmetros do envelope (percentual de abertura na fachada e orientação solar), o desempenho é avaliado em relação à economia de energia, tempo de uso do ar condicionado, período de utilização da ventilação natural e o balanço entre a demanda de energia e os níveis de iluminância. O método é composto por simulações computacionais nos programas Daysim e EnergyPlus. Os resultados mostraram que a estratégia de modo-misto tem um grande potencial para reduzir o consumo do ar condicionado. As grandes reduções ocorreram nos maiores PAFs, atingindo 39,4\% de economia de energia (fachada norte, $P A F=80 \%$ ). Apesar disso, enquanto o maior PAF forneceu maior disponibilidade de ventilação natural, aumentou o desconforto devido a elevadas iluminâncias, atingindo cerca de $90 \%$ da área do escritório. Portanto, quando o modo misto foi usado, os casos com melhor equilíbrio entre níveis adequados de iluminância e baixo consumo de energia foram a fachada sul com todos os PAFs e as fachadas leste e oeste com PAF de 30\%. É importante ressaltar que a adoção destas soluções depende dos requisitos de projeto do edifício.

Palavras-chave: Edifício de modo-misto. Ventilação híbrida. Consumo energético. Níveis de iluminância. Clima tropical de altitude.

How to cite this article:

BRUGNERA, Rosilene Regolão; SANTESSO, Caroline Antonelli; CHVATAL, Karin Maria Soares. Mixed-mode office buildings: energy savings and illuminance levels in a high-altitude tropical climate. PARC Research in Architecture and Building Construction, Campinas, SP, v. 10, p. e019016, apr. 2019. ISSN 1980-6809. Available at: https://periodicos.sbu.unicamp.br/ojs/index.php/parc/article/view/8653027. Date accessed: 26 apr. 2019. doi:https://doi.org/10.20396/parc.v10i0.8653027. 


\section{Introduction}

Office buildings with mixed-mode ( $M M)$ system, also called hybrid ventilation strategy, use both natural ventilation and mechanical cooling systems as a means to provide thermal comfort. According to the Center of Building Environment (CBE, 2017), natural ventilation and the air-conditioning system can operate: in the same space and at the same time; in the same space at different times or; in distinct spaces. Within the benefits of this strategy, reducing energy consumption and user's high satisfaction rates can be highlighted (BRAGER; RING; POWEL, 2000; ROWE; DINH, 2001). Nonetheless, it must be avoided where there is noise, pollution or excessive dust (BRAGER, 2006).

Studies in literature proved the advantages of hybrid ventilation in several climates (SALCIDO; RAHEEM; ISSA, 2016). By using this strategy in arid climates, energy savings related to air-conditioning reached over 40\% (EZZELDIN; REES; COOK, 2009; EZZELDIN; REES, 2013). In a continental climate, savings of 30\% were achieved in the energy use required by the cooling system located in the atrium and corridors during the summer period (KARAVA et al., 2012). In a subtropical climate, savings in energy used for cooling reached up to $35 \%$, and the indoor air quality improved (JI; LOMAS; COOK, 2009). Also, a study in a climate with hot and humid summer in Brazil showed total energy savings over $31.9 \%$ with the adoption of hybrid ventilation (RUPP, 2011). Nevertheless, few studies evaluate the benefits of this strategy in tropical climates, where conditions are favorable for the use of natural ventilation (e.g., in Brazil). Moreover, Brazilian architecture traditionally adopts operable windows, and the occupants are used to operate them during the day (CASATEJADA; CHVATAL, 2017).

In mixed-mode office buildings, natural ventilation can be provided in several ways and controlled by various mechanisms (AGGERHOLM, 2003). For example, there can be air ducts for air distribution (JI; LOMAS; COOK, 2009) and/or windows facing the exterior (GOINS; CHUN; ZHANG, 2013). The control can be fully automated, in response to the monitoring of the exterior climate (KARAVA et al., 2012); partially automated, with an indicative panel, where users can select their preference (DRAKE et al., 2010); or completely in charge of the user (EZZELDIN; REES, 2013). Research studies indicate that operable windows controlled by the occupants make them feel more satisfied and comfortable (MENDLER; ODELL; LAZARUS, 2006; BURTON, 2013).

Operable windows in mixed-mode offices are the source of natural ventilation, lighting and heat gain. They are envelope elements that highly contribute to the increase or decrease of a building's energy consumption. Their characteristics (size, orientation, type of glass, etc.) need to balance adequate illuminance levels, airflow rate, and solar gains, in order to result in the lowest energy consumption possible. Therefore, it is essential to consider the balance between visual and energy demands in studies of mixed-mode buildings with operable windows. Computer simulations performed for mixed-mode office rooms in a city with a hot and humid summer (Florianópolis, Brazil), demonstrated that the window alternatives corresponding to the lowest energy consumption did not always present adequate visual performance (RUPP; GHISI, 2013).

Literature is extensive when dealing with the influence of windows on daylighting levels and on the energy use due to artificial lighting, cooling and/or heating equipment (DUBOIS; BLOMSTERBERG, 2011; SUSOROVA et al., 2013). However, these studies refer only to buildings with no hybrid or natural ventilation strategies, where windows do not provide air exchange for cooling purposes. When dealing with buildings using hybrid ventilation strategies, most of the analyses conducted concentrated on natural ventilation and energy use, not taking into account the daylighting provided by windows (SALCIDO; RAHEEM; ISSA, 2016). 
Considering the above presented context, this paper aims to evaluate the performance of mixed-mode office buildings with operable windows in a high-altitude tropical climate in Brazil. Variations in envelope parameters (Window-to-Wall Ratio - WWR and solar orientation) are considered in order to assess their influence. The performance is evaluated in relation to energy savings, air-conditioning operation hours, period of use of natural ventilation and balance between energy demand and illuminance levels. As a final result, considering the selected climate and the situations studied in this work, design considerations are proposed.

\section{Method}

Considering the above-presented context, this paper aims to evaluate the performance of mixed-mode office buildings with operable windows in a high-altitude tropical climate in Brazil. Variations in envelope parameters (Window-to-Wall Ratio - WWR and solar orientation) are taken into account in order to assess their influence. The performance is evaluated to energy savings, air-conditioning operation hours, the period of use of natural ventilation and balance between energy demand and illuminance levels. As a final result, considering the selected climate and the situations studied in this work, design considerations are proposed.

\section{Simulation programs}

Daysim (version 3.1, NRCC, 2010) was used to simulate natural lighting and its integration with artificial lighting, and EnergyPlus (version 7.2, EERE, 2012) performed the thermal and energy simulations. EnergyPlus' thermal balance calculation is reliable, as it is validated by ASHRAE 140 Standard (ASHRAE, 2014). On the other hand, its natural lighting calculation module was not used, as it overestimates the illuminance values inside the room (DIDONÉ; PEREIRA, 2010; GHISI; TINKER; IBRAHIM, 2005; JAKUBIEC; REINHART, 2011; RAMOS; GHISI, 2010). Daysim, differently, uses the Radiance algorithm, which is a more complex calculation method and generates more precise and detailed data (REINHART; FITZ, 2006; YUN; KIM, 2013).

\section{Climate data}

São Carlos is located in Brazil, at latitude $22^{\circ} 02^{\prime}$ South, altitude of 863 meters, and has a high-altitude tropical climate (Cwa, for the Koppen classification; CEPAGRI, 2016). This climate is characterized by a non-rigorous dry winter and moderately rainy hot summer. This can be verified in Figure 1, whose data refer to the annual weather file, in epw format, developed by Roriz (2012), and used in the simulations in Daysim (NRCC, 2010) and EnergyPlus (EERE, 2012). The minimum monthly mean air temperature varies from 5 to $16^{\circ} \mathrm{C}$, and the maximum from 26 to $34{ }^{\circ} \mathrm{C}$. The air's mean relative humidity is found below $70 \%$ from July to September.

\section{Case study}

The modeled building is an existing eleven-story office building (Frame 1), located in São Carlos (CARRIÈRES, 2007). A rectangular floor plan with office rooms on both sides and a central corridor is a typical design of this type of building. The operable windows are the only source for natural lighting and ventilation, which configures the single-sided ventilation. Despite its limitation, the single-sided ventilation is a cooling solution common to most office building layouts (STABAT; CACIOLO; MARCHIO, 2012). The airconditioning equipment is also wholly user operated. Several studies used this architectural typology, with similar dimensions and proportions as the one presented here (BODART; HERDE, 2002; REINHART; WIENOLD, 2011; RUPP, 2011). 
BRUGNERA, Rosilene Regolão; SANTESSO, Caroline Antonelli; Chvatal, Karin Maria Soares.

Mixed-mode office buildings: energy savings and adequate illuminance levels in a high-altitude tropical climate.

Figure 1 - Weather data for the city of São Carlos, Brazil - Temperature and relative humidity monthly averages

Monthly Minimum, Mean and Maximum

Dry Bulb Temperature $\left({ }^{\circ} \mathrm{C}\right)$ São Carlos

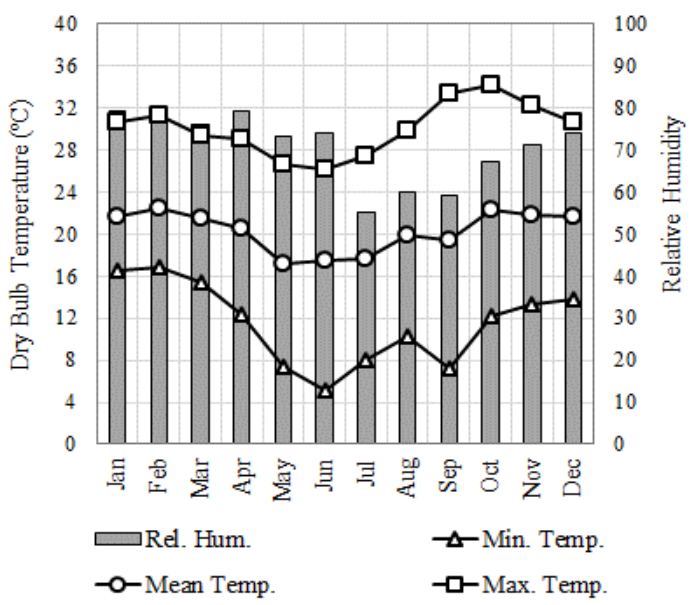

Font: Adapted from EPvieW program, Roriz and Roriz (2015).

Frame 1 - Characteristics of the selected office building and its references floor plan

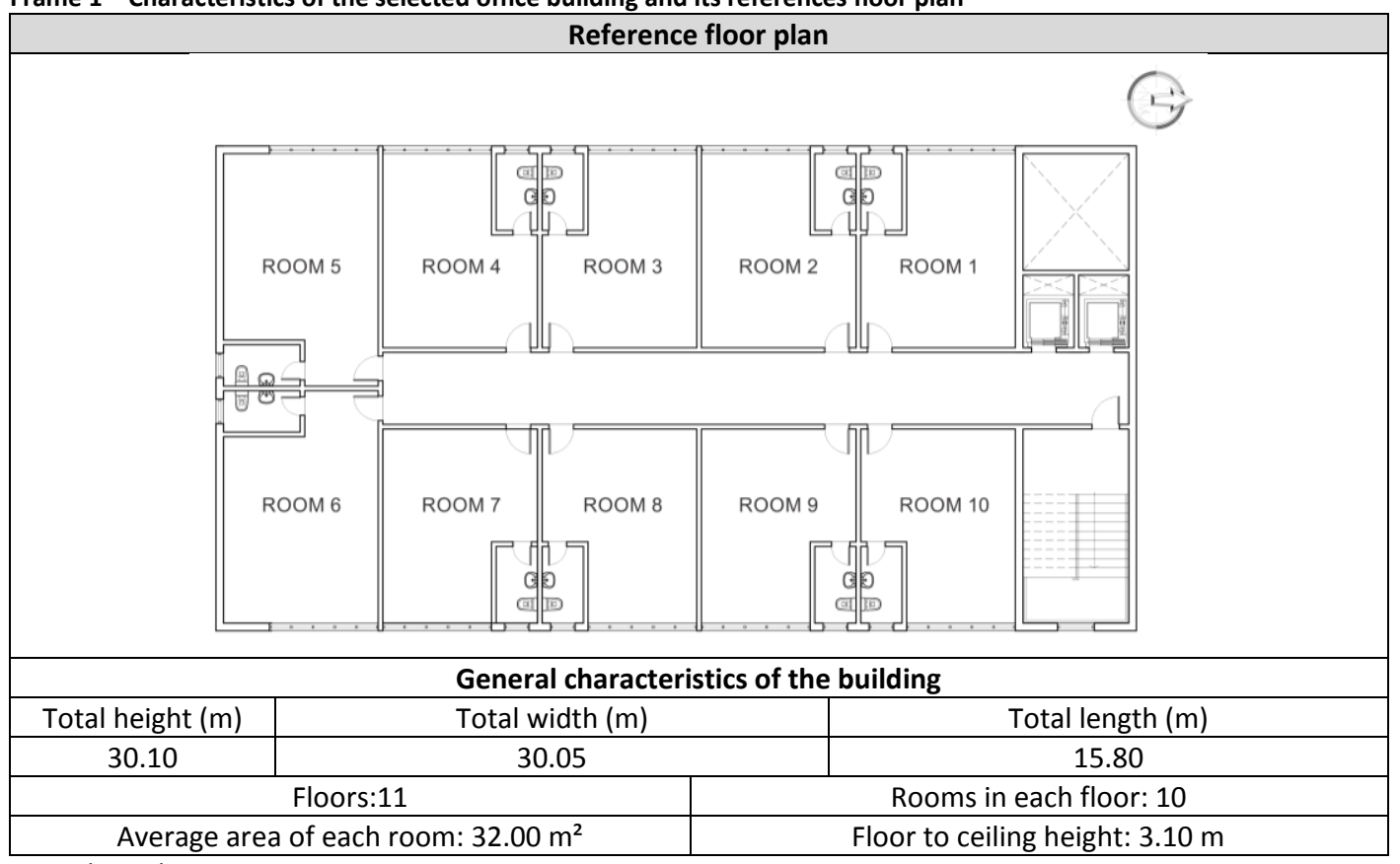

Font: The authors.

A module from the reference floor plan was selected for the study (Figure 2). It is situated on an intermediate floor in the building, and it is composed by two rooms (29.9 $\mathrm{m} 2$ ) with a bathroom (4 m2), a central corridor (13 $\mathrm{m} 2$ ) and a window on each exterior facade. The availability of natural light in the module and the impact on its energy use due to the building characteristics' alterations represent what occurs in the building as a whole (GHISI, 2002; REINHART; WIENOLD, 2011; RUPP, 2011). 
Figure 2 - Simulated module and its geographic orientations
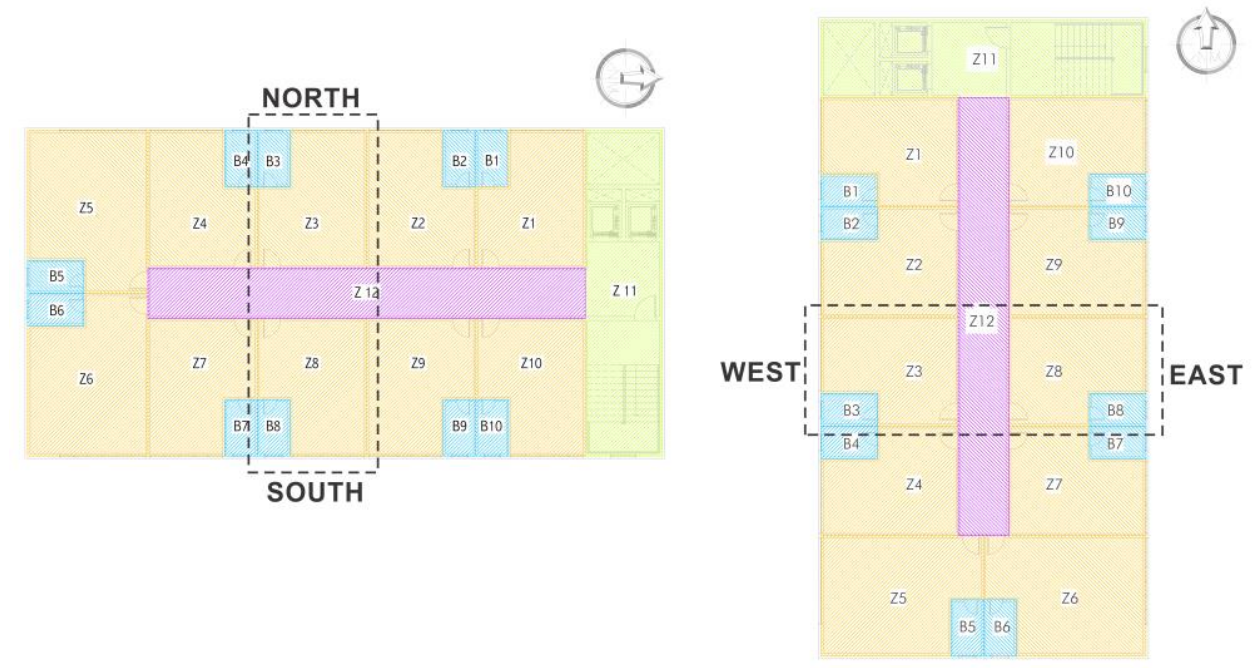

Font: The authors.

Two envelope parameters were varied in the simulations: WWR (window-to-wall ratio) and solar orientation. Three WWR variations were selected, which correspond to what is commonly used in this type of building: minimum (30\%), medium (50\%) and maximum (80\%). As for the orientation, the windows on the exterior facade are facing north and south or east and west. These parameters' combinations resulted in 12 simulations.

\section{Daysim simulations}

The three-dimensional room module was modeled in Daysim (NRCC, 2010) (Figure 3). The surfaces' reflectance was set as $80 \%$ for the ceiling, $60 \%$ for walls and $20 \%$ for the floor. The daylighting illuminances were calculated for 18 points at the work plane at an $80 \mathrm{~cm}$ height (Figure 3). The points are $1.35 \mathrm{~m}$ equidistant, and their quantity was calculated according to the Brazilian Standard NBR 15215-4 (ABNT, 2005).

Figure 3 - Points distribution in the mesh in the office

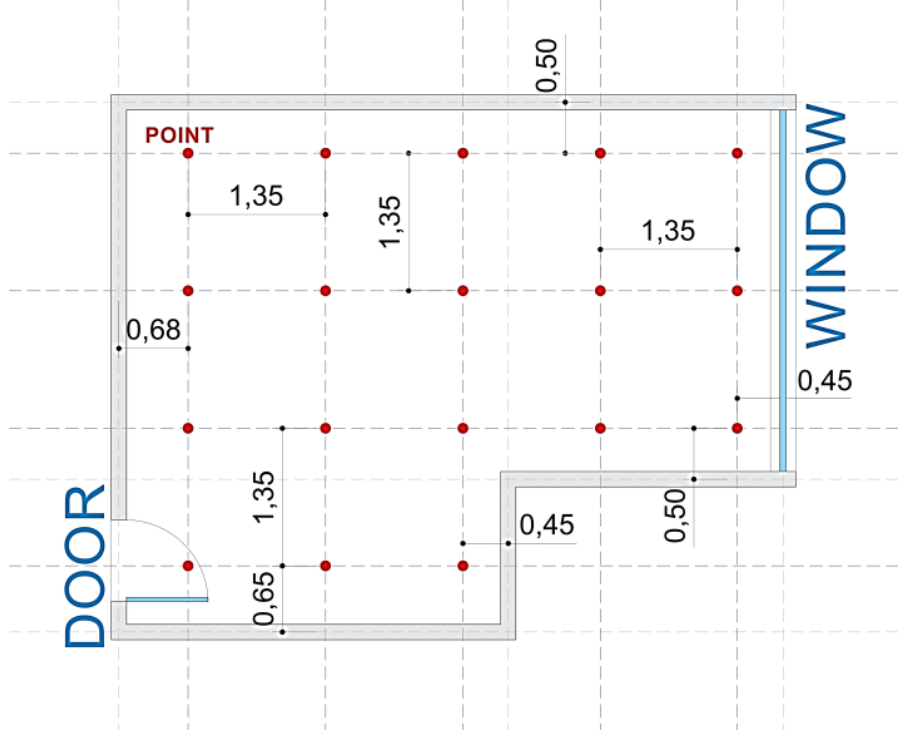

Font: The authors.

The Lighting Power Density (LPD) is of $12 \mathrm{~W} / \mathrm{m}^{2}$ (Office room by ASHRAE, 2013). A light dimming system was modeled to complement daylighting levels below 500 lux 
(minimum required for office activities according to the Brazilian standard NBR ISO/CIE 8995-1 - ABNT, 2013), during the occupied hours, from 8 am to 6 pm, on weekdays. An active users' option was selected, which corresponds to an automatic dimming. This option guarantees a better integration between natural and artificial lighting, and therefore lower energy consumption.

\section{EnergyPlus simulations}

A building module with five thermal zones (Figure 2) was simulated. The interior walls, floor, and ceiling were considered adiabatic, assuming that the indoor air temperature was the same on the floors immediately above and below, the bathrooms, the adjacent rooms, and the corridor. The building's constructive components are specific to the existing building (Table 1).

Table 1 - Constructive components and their thermo physical properties

\begin{tabular}{|c|c|c|c|}
\hline Constructive component & U-value $\left(w / m^{2} k\right)^{1}$ & \multicolumn{2}{|c|}{ Absorptance $^{2}$} \\
\hline EXTERNAL WALLS & \multirow{2}{*}{2.62} & Solar & 0.39 \\
\hline Exterior mortar $(2.5 \mathrm{~cm})+$ concrete blocks $(19 \mathrm{~cm})+$ interior mortar $(2.5 \mathrm{~cm})$ & & Visible & 0.40 \\
\hline INTERNAL WALLS & \multirow{2}{*}{2.27} & \multirow{4}{*}{\multicolumn{2}{|c|}{-}} \\
\hline Exterior mortar $(2.5 \mathrm{~cm})+$ concrete blocks $(9 \mathrm{~cm})+$ interior mortar $(2.5 \mathrm{~cm})$ & & & \\
\hline INTERMEDIATE FLOOR & \multirow{2}{*}{2.04} & & \\
\hline Concrete slab $(8 \mathrm{~cm})$ & & & \\
\hline GLASS TYPE $^{3}$ & \multicolumn{3}{|c|}{ Single clear glass $6 \mathrm{~mm}$} \\
\hline \multicolumn{4}{|c|}{${ }^{1}$ Calculated according to the Brazilian standard NBR 15220 (ABNT, 2005) } \\
\hline \multicolumn{4}{|c|}{${ }^{2}$ The real building color was estimated according to the various paint colors measured by Dornelles (2008). } \\
\hline \multicolumn{4}{|c|}{${ }^{3}$ According to EnergyPlus Datasets } \\
\hline
\end{tabular}

Four occupants with typing activity (metabolic rate of $65 \mathrm{~W} / \mathrm{m}^{2}$; EERE, 2012) were considered in each room. The occupation period was considered weekdays, from 8 am to $6 \mathrm{pm}$, with a 2-hour lunch break (from $12 \mathrm{pm}$ to $2 \mathrm{pm}$ ). The equipment load density (four computers) was equivalent to $15 \mathrm{~W} / \mathrm{m}^{2}$ (ABNT, 2008). They remained ON during the entire occupied period, staying in standby (half of their capacity) during the lunch break. The artificial lighting's hourly annual power was provided by Daysim (NRCC, 2010). This software generates a data sheet of the artificial lighting operation, depending on the need to complement natural lighting.

Two air-conditioning scenarios were modelled (Figure 4).

- Full-time air-conditioning scenario (FTAC): The equipment was activated from 8 am to $6 \mathrm{pm}$ for cooling or heating, depending on the setpoint temperature for air-conditioning (STPaC) $\left(25^{\circ} \mathrm{C}\right.$ or $18{ }^{\circ} \mathrm{C}$, respectively). The window remained closed.

- Mixed-mode scenario (MM): This model is identical to the previous one regarding the air-conditioning activation. Nevertheless, the window was opened for natural ventilation when indoor air temperature (Tind) was between $20^{\circ} \mathrm{C}$ (setpoint temperature for natural ventilation - STPnv) and $25^{\circ} \mathrm{C}$ (setpoint temperature for air-conditioning - STPac), and also higher than the outdoor air temperature (Tout). The air-conditioning setpoint temperature $\left(25{ }^{\circ} \mathrm{C}\right)$ for mixed-mode offices was obtained from previous studies (BRUGNERA, RORIZ; CHVATAL, 2013; BRUGNERA, 2014).

There are many types of air-conditioning equipment, and most of them require specific information about their systems. Thus, to simplify the EnergyPlus simulation, the ideal air-conditioning system was adopted. This system is used when the user wishes to study 
the performance of a building without modeling a full HVAC system (EERE, 2013). Therefore, a conversion to obtain a real air-conditioning consumption was necessary. For this purpose, a Split type air-conditioning was selected. Thus, the cooling load (generated in the simulation with the ideal air-conditioning) was divided by the energy efficiency coefficient of the Split system, which is $3.2 \mathrm{~W} / \mathrm{W}$ for level A appliances (INMETRO, 2018).

Figure 4- Air-conditioning operation and window opening in the FTAC and MM scenarios, during occupied hours

\begin{tabular}{c|ccc} 
Full-time air-conditioning (FTAC) scenario & Mixed-mode (MM) scenario \\
Air conditioning for \\
Cooling is required
\end{tabular}

Font: The authors.

Natural ventilation was simulated using the Airflow Network module for the reference floor plan at the height of $15 \mathrm{~m}$. Since the geometry is a rectangular shape, the program automatically provided the wind pressure coefficients (average values per facade). The internal doors were modeled closed and the window type with an effective ventilation area of $100 \%$. An isolated building was considered.

\section{Result analysis}

The hybrid ventilation performance for distinct combinations of WWR and orientation for the analyzed climate was first assessed by comparing the MM and FTAC scenarios. This evaluation allowed to observe if and when the air-conditioning was activated, or if the windows were opened and the resultant energy savings. The room heat gains and losses were analyzed in order to understand the impact of the hybrid ventilation and the various WWRs on the office's thermal balance. Finally, the impact of WWR and solar orientation on energy consumption and daylighting metrics were assessed, only for the room in the MM scenario. Thus, considerations about the design for this type of building were made, considering the studied parameters.

Air-conditioning consumption levels for the simulations in the MM scenario were established from 1 to 3 (from best to worst), as shown in Frame 2. This procedure is analogous to the one adopted in the Brazilian Regulation (INMETRO, 2014), which establishes the energy efficiency levels (from $A$ to $E$ ) of a particular building.

The adopted daylighting levels' metrics were the most commonly used in literature (REINHART; WIENOLD, 2011; YU; SU, 2015).

- Daylight Autonomy (DA): represented as a percentage of annual daytime hours that a given point in space is above a specified illumination level. This parameter was the same adopted by many other computer simulation studies (REINHART; 
WEISSMAN, 2012; DUBOIS; FLODBERG, 2012; HEGAZY; ATTIA; MORO, 2013; RUPP; GHISI, 2013; MASHALY et al., 2015; RAIMONDI et al., 2016). A percentage of the room area was calculated and categorized in specific ranges of DA. This criterion was created to allow an assessment and a classification of the entire room, which is necessary to perform illuminance levels and energy consumption integrated analysis.

- Useful Daylight Illuminance above 2000 lux (UDI > 2000): corresponds to the percentage of occupied hours in a year during which the illuminance is above 2000 lux in each point of the work plane. This kind of situation could increase the risk of visual discomfort by glare, due to the intense amount of natural light in the room (NABIL; MARDALJEVIC, 2006). This criterion was used taking into account several studies that also considered this limit to be an adequate illuminance level (CANTIN; DUBOIS, 2011; RUPP; GHISI, 2013; ZHOU; LIU, 2015; DALLA MORA et al., 2018; TABADKANI; BANIHASHEMI; HOSSEINI, 2018). However, it is known that in certain conditions this limit can be higher (BREMBILLA; HOPE; MARDALJEVIC, 2018). This limit was adopted because natural lighting is a complex phenomenon and a metric that allows the combined analysis of illuminance levels and energy consumption should be established. In order to allow the analysis of the entire room, the room area in which the UDI > 2000 was calculated and categorized in specific ranges (similar to DA).

Frame 2 - Energy consumption classification for the MM scenario

\begin{tabular}{|c|c|c|}
\hline \multicolumn{3}{|c|}{ Consumption level } \\
\hline 1 & 2 & 3 \\
\hline$V<$ Min+1C & $\operatorname{Min}+1 C \leq V \operatorname{Min}+2 C$ & $\mathrm{~V} \geq \operatorname{Min}+2 \mathrm{C}$ \\
\hline $\begin{array}{l}\text { Min = minimum annual consum } \\
\text { Max = maximum annual consun } \\
\mathrm{C}=[(\text { Max-Min }) / 3] \\
\text { V = annual consumption value } \\
\text { Values in } \mathrm{kWh} /\left(\mathrm{m}^{2} \text {.year }\right)\end{array}$ & $\begin{array}{l}\text { obtained for all simula } \\
\text { e obtained for all simula }\end{array}$ & $\begin{array}{l}\text { o) } \\
\text { io) }\end{array}$ \\
\hline
\end{tabular}

Table Font: The authors.

Two daylighting levels were established for DA and UDI > 2000, as indicated in Frame 3. DA level 1 (best) relates to more than $60 \%$ of the room's area with $D A>50 \%$ of the occupied hours in a year and also less than $20 \%$ of the area with $\mathrm{DA}<20 \%$. The other level was established in an analogous manner, as well as those relative to the UDI > 2000. The illuminance levels' classification was created analogous to the energy consumption levels. These levels refer to a combination of the illuminance and energy consumption levels data for this particular studied case.

Frame 3 - Illuminance levels classification

\begin{tabular}{|c|c|c|c|c|}
\hline \multirow{3}{*}{ Level } & \multicolumn{4}{|c|}{ Percentage of room area } \\
\hline & \multicolumn{2}{|c|}{$\mathrm{DA}$} & \multicolumn{2}{|c|}{ UDI $>2000$} \\
\hline & $<20 \% *$ & $>50 \% *$ & $<20 \% *$ & $>50 \% *$ \\
\hline 1 & $\begin{array}{c}\text { Less than } 20 \% \text { of the } \\
\text { room's area }\end{array}$ & $\begin{array}{c}\text { More than } 60 \% \text { of the } \\
\text { room's area }\end{array}$ & $\begin{array}{l}\text { More than } 60 \% \\
\text { of the room's } \\
\text { area }\end{array}$ & $\begin{array}{c}\text { Less than } 20 \% \text { of the } \\
\text { room's area }\end{array}$ \\
\hline 2 & $\begin{array}{l}\text { Less than } 33 \%(1 / 3) \\
\text { of the room's area }\end{array}$ & - & - & $\begin{array}{c}\text { Less than } 33 \%(1 / 3) \text { of } \\
\text { the room's area }\end{array}$ \\
\hline 3 & $\begin{array}{c}\text { Greater than or equal } \\
\text { to } 1 / 3 \text { of the room's } \\
\text { area }\end{array}$ & - & - & $\begin{array}{l}\text { Greater than or equal to } \\
1 / 3 \text { of the room's area }\end{array}$ \\
\hline
\end{tabular}




\section{Results and discussion}

\section{MM scenario versus FTAC scenario: air-conditioning operation and window opening}

In the MM (mixed-mode) and FTAC (full-time air-conditioning) scenarios, the mechanical system was never activated for heating, because the indoor temperature in the occupied period (daytime) was never below $18{ }^{\circ} \mathrm{C}$ (setpoint for heating).

Figures $5^{(1)}$ refer to the room facing north, with a WWR of $50 \%$, for both scenarios (MM and FTAC).

In the FTAC scenario, the air-conditioning was necessary during more than $87 \%$ of the occupied hours, in all months of the year (Figure 5a), as indoor air temperature reached $25^{\circ} \mathrm{C}$ during most of this period (Figure $5 \mathrm{~b}$ ). In the MM scenario, the air-conditioning remained activated from $25 \%$ to $79 \%$ of the month's occupied hours, while the windows remained open in the remaining period (Figure $5 \mathrm{a}$ ). Similar results were also verified in other studies (RUPP; GHISI, 2012; WANG; GREENBERG, 2015).

Figure $5 \mathrm{C}$ allows verifying in further detail what occurred in the MM scenario during the seasons of the year.

- Summer (February): the window was open especially in the beginning of the occupied period, (Tind $<25^{\circ} \mathrm{C}$ and Tout $<$ Tind). However, by the end of the morning, the outdoor and indoor temperatures increased, and the airconditioning was activated until the end of the day.

- Fall (April) and winter (July): the period when the indoor temperature reached $25^{\circ} \mathrm{C}$, and the air-conditioning was activated gradually decreased. Windows were opened in the remaining period, as indoor temperature remained higher than outdoor temperature and within $20^{\circ} \mathrm{C}$ (STPnv) and $25^{\circ} \mathrm{C}$ (STPac). Windows did not have to be closed due to low indoor temperatures.

- Spring (October): the behavior was similar to the summer period (February).

All other studied cases (other WWRs and/or orientations) presented the same results pattern:

- Considerable reduction of air-conditioning use time with the adoption of the mixed-mode approach. When the air-conditioning was not activated, the windows remained open, indicating a great potential to use natural ventilation in the studied climate.

- Windows opened for ventilation in the early morning, in the summer, with periods throughout the day when they were closed, due to the increase of internal and external temperatures. A gradual increase in the ventilation period in the autumn and winter, while the need to close windows was not identified due to low temperatures.

Natural ventilation, in all simulations, was single-sided, with a window in only one facade and $100 \%$ opening area for ventilation. For the case presented in Figure $5 \mathrm{c}$, during the hours when the windows were open, the maximum assumed values for the monthly mean air change rate varied from $15 \mathrm{ACH}$ (between 10 am to $11 \mathrm{am}$, October) to $33 \mathrm{ACH}$ (between 10 am to $11 \mathrm{am}$, July), for the studied climate. 
BRUGNERA, Rosilene Regolão; SANTESSO, Caroline Antonelli; Chvatal, Karin Maria Soares.

Mixed-mode office buildings: energy savings and adequate illuminance levels in a high-altitude tropical climate.

Figure 5 - Air-conditioning and natural ventilation (a), temperature and airflow rate in FTAC (b) and MM (c) scenarios

(a)

Air-conditioning operation and window opening in FTAC and MM scenarios, North Facade, WWR 50\%

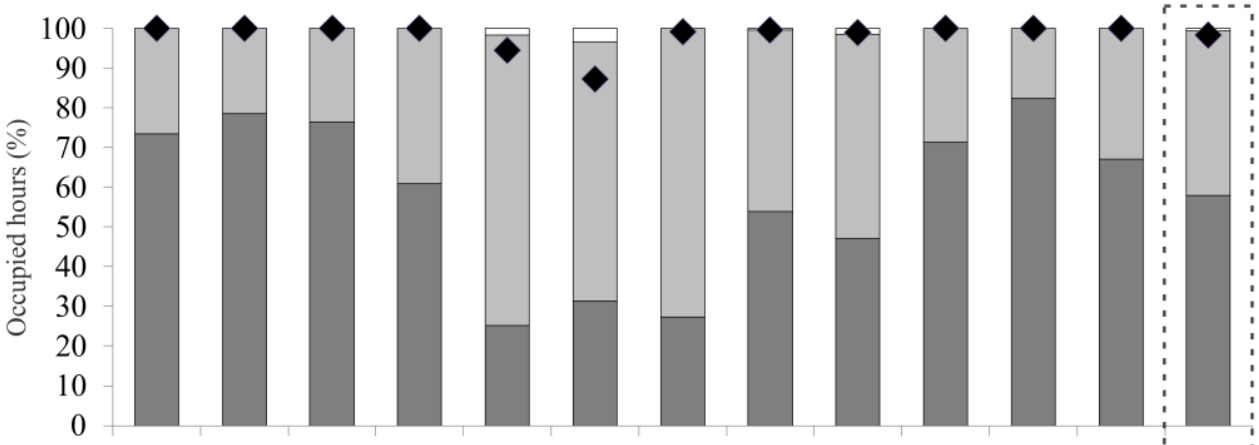

Jan Feb Mar Apr May Jun Jul Aug Sept Oct Nov Dec:Year

\begin{tabular}{|c|c|c|}
\hline FTAC & Air-conditioning & $\square$ Air-conditioning \\
& $\begin{array}{l}\text { No air-conditioning } \\
\text { and closed windows } \\
\text { (\% remaining hours) }\end{array}$
\end{tabular} \mid $\begin{array}{ll}\text { MM } & \square \text { Natural ventilation } \\
& \square \text { No air-conditioning and no natural ventilation }\end{array}$

(b) FTAC:Office temperature and airflow rate average hours, North Facade, WWR 50\%

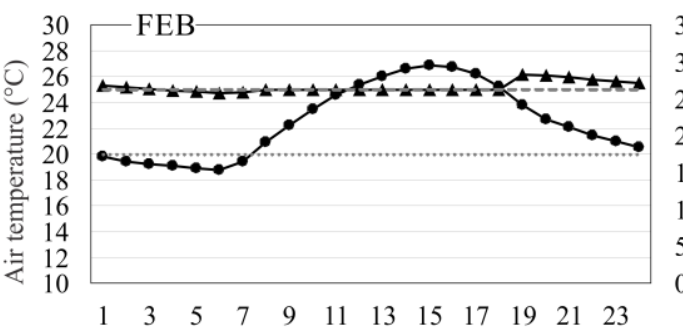

$\rightarrow$ Tout

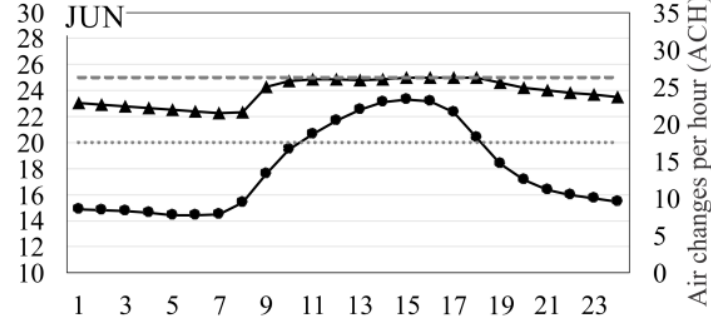

-...STPny --STPac

(c) MM:Office temperature and airflow rate average hours, North Facade, WWR 50\%

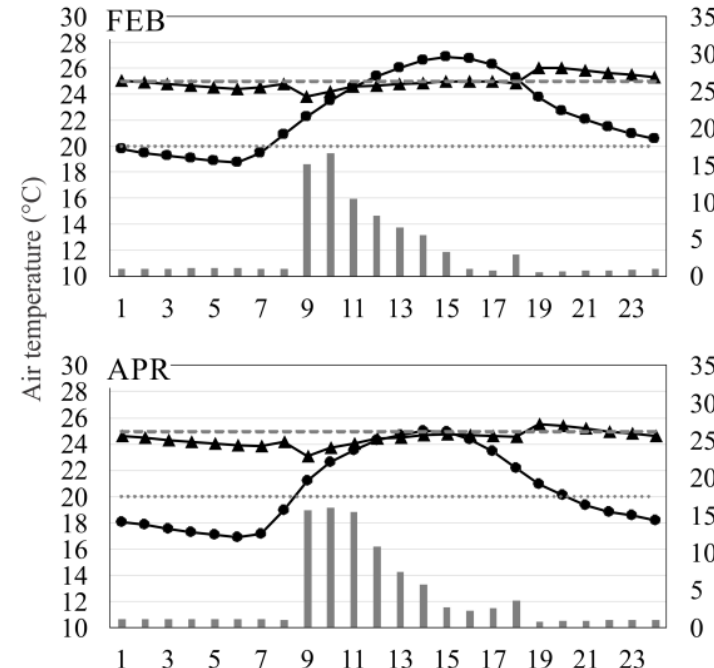

Room Air Change Rate
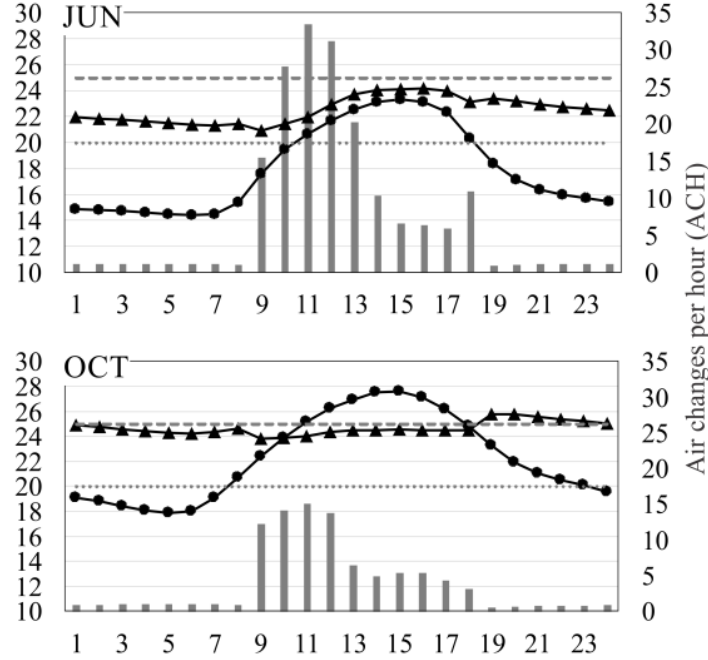

- Tind

--STPac

FTAC $=$ Full-time air-conditioning scenario $\mid \mathrm{MM}=$ Mixed-mode scenario

Tout $=$ outdoor air temperature $\mid$ Tind $=$ indoor air temperature

$\mathrm{STPnv}=$ setpoint temperature for natural ventilation $\mid \mathrm{STPac}=$ setpoint temperature for air-conditioning Font: The authors. 


\section{MM scenario versus FTAC scenario: energy saving potential}

The MM scenario resulted in an air-conditioning consumption decrease, from 13.6 to $39.4 \%$ (indicated in the vertical boxes, Figure 6), according to WWR and solar orientation. This corresponds to a decrease of 3.6 to $26.8 \%$ in the total energy consumption. These values are in accordance to the studies performed with mixedmode buildings in arid and continental climates, with a reduction of the energy consumed by the mechanical cooling system close to 40\% (EZZELDIN; REES, 2013; KARAVA et al., 2012; Jl; LOMAS; COOK, 2009). Figure 6 shows only the air-conditioning's energy consumption, but the same results, regarding the impact of WWR, and solar orientation, were found for the building's total consumption (lighting, equipment and air-conditioning consumption combined), due to the fixed equipment consumption and the low lighting consumption (as a result of the dimmable system).

In both scenarios, the increase of WWR generates an increase of the air-conditioning consumption (Figure 6). This occurs more clearly in the FTAC scenario than in the MM scenario. In the MM scenario, the energy saving potential with hybrid ventilation is higher for larger windows, considering this room type, shape, and climate (vertical boxes, in Figure 6).

Figure 6- Annual cooling energy consumption for the FTAC and MM scenarios

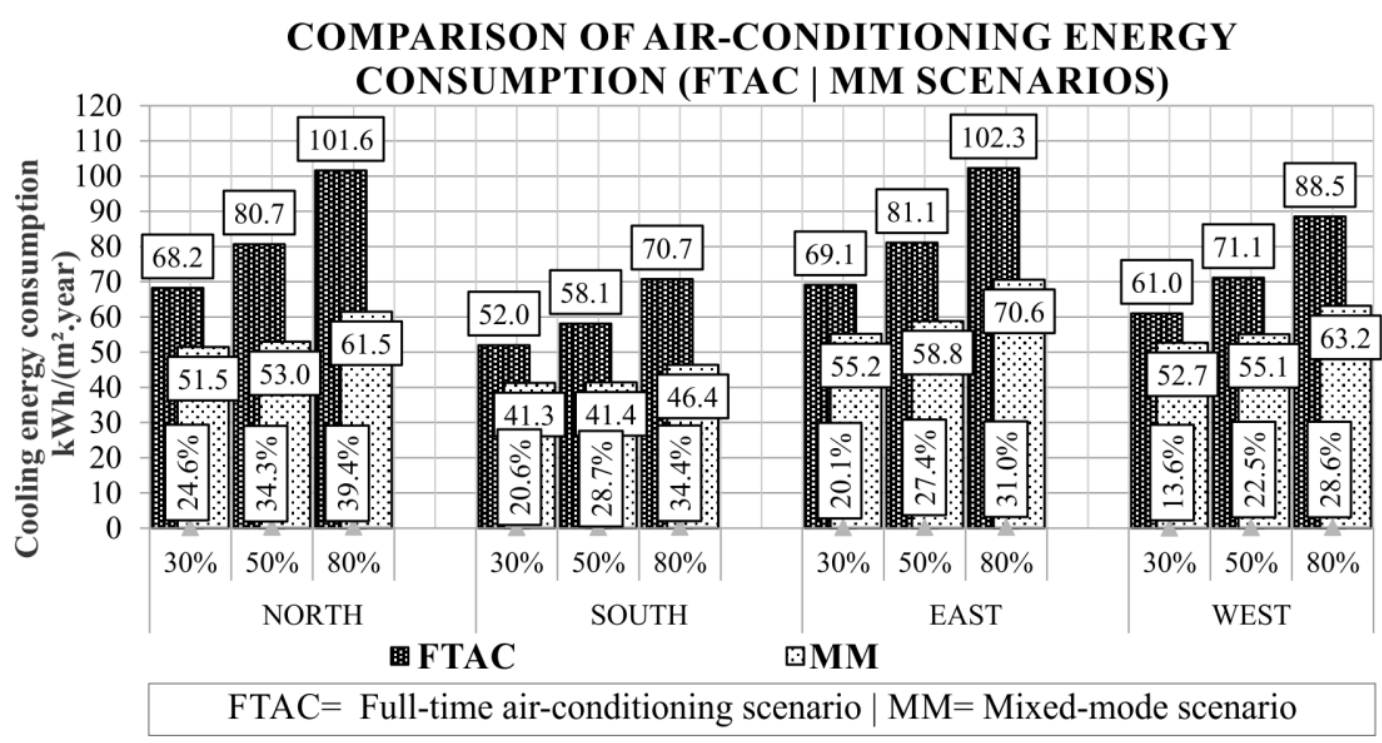

Font: The authors.

Rupp and Ghisi (2013) also confirmed this phenomenon for rooms with similar areas and characteristics to the one studied here, which can be explained by the room's annual thermal balance, presented in Figure 7. In both scenarios, as the WWR increases, solar gains also increase, requiring more heat to be removed from the interior. In the FTAC scenario, this excessive heat is lost through the envelope and removed by the airconditioning, resulting in a considerable increase in the mechanical system's consumption, as the WWR increases. As for the MM scenario, the heat loss increases with the increase of the window opening on the facade, due to the use of natural ventilation. Therefore, there is no need for a significant increase in the mechanical system's consumption. 
BRUGNERA, Rosilene Regolão; SANTESSO, Caroline Antonelli; Chvatal, Karin Maria Soares.

Mixed-mode office buildings: energy savings and adequate illuminance levels in a high-altitude tropical climate.

Figure 7- Heat balance in the office facing north and with all the WWRs considered (FTAC and MM scenarios)

HEAT GAIN AND LOSS IN OFFICE ROOM

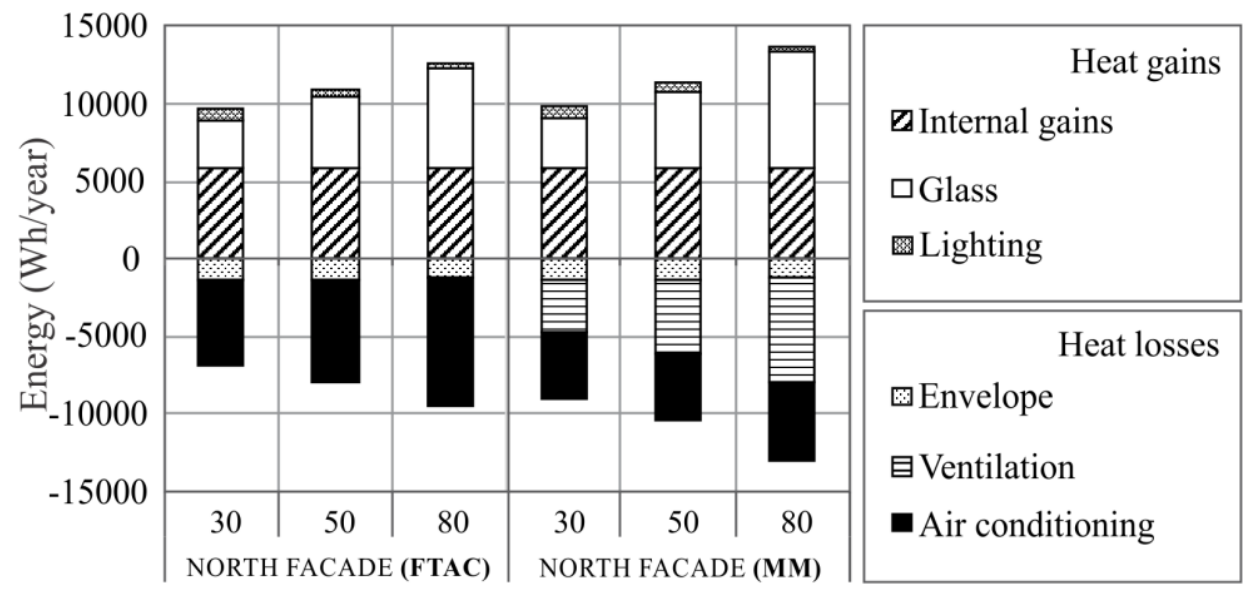

Font: The authors.

MM scenario: design considerations regarding energy consumption and illuminance levels

Energy consumption and illuminance levels of the MM simulations were classified in three levels (from 1, best, to 3, worst). These results are presented in Table 5 and are discussed below.

Table 5 - Comparison between energy consumption and illuminance levels

\begin{tabular}{|c|c|c|c|c|c|c|c|c|c|c|c|c|}
\hline \multicolumn{5}{|c|}{ Energy consumption } & \multicolumn{8}{|c|}{ Illuminance levels } \\
\hline & & \multirow[b]{2}{*}{ WWR } & \multirow{2}{*}{$\begin{array}{c}\text { Air- } \\
\text { conditioning's } \\
\text { energy } \\
\text { consumption } \\
\text { in mixed- } \\
\text { mode } \\
\mathrm{kWh} /\left(\mathrm{m}^{2} \text {.year }\right)\end{array}$} & \multirow[b]{2}{*}{$\begin{array}{c}\text { Energy } \\
\text { consumption } \\
\text { level }\end{array}$} & \multicolumn{3}{|c|}{ Room area (\%) } & \multirow[b]{2}{*}{$\begin{array}{c}\text { DA } \\
\text { level }\end{array}$} & \multicolumn{3}{|c|}{ Room area (\%) } & \multirow[b]{2}{*}{$\begin{array}{c}\text { UDI }_{>\mathbf{2 0 0 0}} \\
\text { level }\end{array}$} \\
\hline & & & & & $\begin{array}{c}\text { DA } \\
<20 \%\end{array}$ & $\begin{array}{c}20 \%<= \\
\text { DA <= } \\
50 \%\end{array}$ & $\begin{array}{c}\text { DA } \\
>50 \%\end{array}$ & & $\mathrm{UDI}_{>\mathbf{2 0 0 0}}<20 \%$ & $\begin{array}{c}20 \%<= \\
\mathrm{UDI}_{>2000}<= \\
50 \%\end{array}$ & $\begin{array}{c}\text { UDI }_{>2000} \\
>50 \%\end{array}$ & \\
\hline \multirow{12}{*}{ 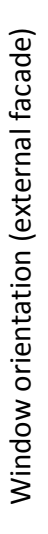 } & \multirow{3}{*}{ 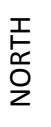 } & 30 & 51.5 & 2 & $11 \%$ & $17 \%$ & $72 \%$ & 1 & $61 \%$ & $6 \%$ & $33 \%$ & 3 \\
\hline & & 50 & 53.0 & 2 & $6 \%$ & $6 \%$ & $89 \%$ & 1 & $50 \%$ & $11 \%$ & $39 \%$ & 3 \\
\hline & & 80 & 61.5 & 3 & $0 \%$ & $6 \%$ & $94 \%$ & 1 & $50 \%$ & $17 \%$ & $33 \%$ & 3 \\
\hline & \multirow{3}{*}{$\begin{array}{l}\text { エ } \\
\stackrel{5}{\supset} \\
\text { ○ }\end{array}$} & 30 & 41.3 & 1 & $33 \%$ & $17 \%$ & $50 \%$ & 3 & $67 \%$ & $33 \%$ & $0 \%$ & 1 \\
\hline & & 50 & 41.4 & 1 & $17 \%$ & $17 \%$ & $67 \%$ & 1 & $67 \%$ & $0 \%$ & $33 \%$ & 3 \\
\hline & & 80 & 46.4 & 1 & $6 \%$ & $11 \%$ & $83 \%$ & 1 & $56 \%$ & $0 \%$ & $44 \%$ & 3 \\
\hline & \multirow{3}{*}{ 卢 } & 30 & 55.2 & 2 & $28 \%$ & $22 \%$ & $50 \%$ & 2 & $67 \%$ & $28 \%$ & $6 \%$ & 1 \\
\hline & & 50 & 58.8 & 2 & $6 \%$ & $28 \%$ & $67 \%$ & 1 & $67 \%$ & $0 \%$ & $33 \%$ & 3 \\
\hline & & 80 & 70.6 & 3 & $0 \%$ & $11 \%$ & $89 \%$ & 1 & $50 \%$ & $17 \%$ & $33 \%$ & 3 \\
\hline & \multirow{3}{*}{ 点 } & 30 & 52.7 & 2 & $17 \%$ & $22 \%$ & $61 \%$ & 1 & $67 \%$ & $17 \%$ & $17 \%$ & 1 \\
\hline & & 50 & 55.1 & 2 & $6 \%$ & $11 \%$ & $83 \%$ & 1 & $56 \%$ & $11 \%$ & $33 \%$ & 3 \\
\hline & & 80 & 63.2 & 3 & $0 \%$ & $6 \%$ & $94 \%$ & 1 & $28 \%$ & $11 \%$ & $61 \%$ & 3 \\
\hline
\end{tabular}

Font: The authors.

\section{Influence of WWR and solar orientation on energy consumption}

Regarding energy consumption, the south facade can be highlighted, being classified as level 1 for all WWRs, due to two factors. For the studied latitude ( $22^{\circ} 02^{\prime}$ South), solar heat gains on the south facade are much lower than the other orientations (north, east and west). Besides that, as previously presented in Figures 6 and 7, the potential to 
remove heat with natural ventilation increases as the opening area increases. Thus, the energy consumption values for distinct WWRs were close.

In comparison to the south facade, the north, west and east facades presented higher energy consumption, reaching level 2 for the WWRs of 30 and 50\%, and level 3 for the WWR of $80 \%$. This is due to the higher solar incidence on these facades throughout the year. Besides, the increase in WWR causes an increase in heat gains, even with intensified natural ventilation. In this case, natural ventilation is not enough to efficiently remove the heat, as occurs in the south facade, requiring a higher thermal demand from the mechanical system.

\section{Influence of WWR and solar orientation on illuminance levels}

Daylight autonomy and the risk of glare were the two metrics chosen to evaluate natural light. As the WWR decreases, there is less availability of natural light, which means that there is also a smaller room area with daylight autonomy, in any solar orientation. The worst situations, among the simulated scenarios, were those with smaller windows (WWR of 30\%) facing east or south (classified as level 2 and 3, respectively).

Regarding the risk of glare, the effect was the opposite, with the best situations being those with less light availability. According to the adopted criterion, the same situations identified as the worst scenarios for daylight autonomy (WWR of 30\% in the south and east orientations) were classified as level 1 , in addition to the case with WWR of $30 \%$ and facade facing west. All other cases were classified as level 3. This could make the positioning of workstations a difficult task and could lead to adopting inefficient palliative solutions, which could significantly reduce the amount of natural light and hinder the opening of windows (CANTIN; DUBOIS, 2011).

Balance between energy demand and illuminance level

The south-facing facade was the solar orientation presenting lower energy consumption for the climate and type of building studied, with values closer to each other for all WWRs (all classified as level 1). In this case, the WWR would be chosen according to the design priorities for natural lighting. These priorities are: a lower risk of glare, but also less daylight autonomy (WWR of 30\%, with levels 3 for autonomy of light and 1 for the risk of glare) or a better daylight autonomy and higher risk of glare (WWRs of 50 and $80 \%$ with levels 1 for the daylight autonomy and 3 for the risk of glare).

The north, east and west facades with WWR of $80 \%$ were classified as having the highest energy consumption and risk of glare (level 3 for both criteria), despite their high daylight autonomy (level 1). Large window areas in these orientations should, therefore, be avoided in the studied building.

The north, east and west facades with WWR of 30 and 50\% presented intermediate energy consumption (level 2). However, their risk of glare varied, alternating between levels 1 and 3. The cases with low risk of glare (level 1, east and west facades, with WWR of 30\%) presented high or intermediate daylight autonomy (level 1 for the west facade and level 2 for the east facade). Therefore, these cases could be considered as solutions with a balance between energy consumption, a risk of glare and daylight autonomy. The same does not occur for the cases with high risk of glare (level 3, north facade with WWR of 30 and $50 \%$ and facades east and west with WWR of $50 \%$ ). This aspect, combined with no significant reduction in energy consumption (level 2), represents a less favorable solution, despite the high daylight autonomy (level 1 for all cases). 


\section{Conclusions}

Hybrid ventilation proved to be a strategy of great potential for office buildings with operable windows located at a high-altitude tropical climate. The air-conditioning operation hours were reduced, allowing natural ventilation to occur during most of the remaining occupancy period. The most significant use of natural ventilation was observed in the colder months (May to July). The annual cooling energy savings potential, for the studied case, varied between 13.6 and 39.4\%, which is in accordance with the literature.

When hybrid ventilation is used, the cases with a better balance between adequate illuminance levels and low energy consumption were the south facade with WWRs of $30 \%, 50 \%$, and $80 \%$, and east and west facades with WWR of 30\%. Nonetheless, these scenarios presented problems, such as high risk of glare, low or intermediate daylight autonomy levels or intermediate energy consumption. Therefore, adopted solutions depend on the building's design requirements.

It is important to highlight that the conclusions from this study refer to the situations here analyzed, which correspond to a hybrid ventilated building operated by an ideal control system and single-sided natural ventilation with an opening window area of $100 \%$.

For future research studies, the use of movable shading devices that would better distribute the light is suggested, since it could decrease the risk of glare without increasing artificial lighting activation. Also, it would also be essential to measure the devices' impact on natural ventilation conditions, so that the strategy could be properly implemented and perform satisfactorily. Therefore, the resultant low energy consumption could be combined to provide adequate illuminance levels. The authors also suggest new research studies on measuring energy consumption considering the users' real behavior, which could be obtained through field research.

\section{Acknowledgements}

The work reported in this paper was supported by grant \#2012/18138-6, São Paulo Research Foundation (FAPESP).

\section{Notes}

(1) Figures $5 \mathrm{a}$ and $5 \mathrm{~b}$ show the representative months for the outdoor and indoor air temperatures' variations, and the resulting window opening or closing for the city of São Carlos, Brazil, located in the Southern hemisphere. In the FTAC scenario, two behavior patterns were found, represented by the months of February (warmer period) and July (colder period). In the MM scenario, these patterns are defined according to the seasons; summer (represented by February), fall (April), winter (July) and spring (October).

\section{References}

ABNT - ASSOCIAÇÃO BRASILEIRA DE NORMAS TÉCNICAS. NRB ISO/CIE 8995-1-2013: Iluminação de ambientes de trabalho Parte 1: Interior. Rio de Janeiro, 2013.

ABNT - ASSOCIAÇÃO BRASILEIRA DE NORMAS TÉCNICAS. NBR 15220-3-2005: Desempenho térmico de edificações Parte 3: Zoneamento bioclimático brasileiro e diretrizes construtivas para habitações unifamiliares de interesse social, Rio de Janeiro, RJ, Brasil, 2005.

ABNT - ASSOCIAÇÃO BRASILEIRA DE NORMAS TÉCNICAS. NBR 15215-4-2005: lluminação natural - Parte 4: Verificação experimental das condições de iluminação interna de edificações - Método de medição. Rio de Janeiro, 2005. 
ABNT - ASSOCIAÇÃO BRASILEIRA DE NORMAS TÉCNICAS. NBR 16401-1-2008: instalações de ar-condicionado, sistemas centrais e unitários: parte 1: projetos das instalações. Rio de Janeiro, 2008.

AGGERHOLM, S. Control of Hybrid Ventilation Systems. International Journal of Ventilation, v. 1, n. 4, p. $65-75$, 2003. DOI:https://doi.org/10.1080/14733315.2003.11683645.

ASHRAE - AMERICAN SOCIETY OF HEATING, REFRIGERATING AND AIR-CONDITIONING ENGINEERS. ASHRAE Standard 90.1-2013: Energy Standard for Buildings Except Low-Rise Residential Buildings. Atlanta, 2013.

ASHRAE - AMERICAN SOCIETY OF HEATING, REFRIGERATING AND AIR-CONDITIONING ENGINEERS. ASHRAE Standard 140-2014: Standard Method of Test for the Evaluation of Building Energy Analysis Computer Programs. Atlanta, 2014.

BODART, M.; HERDE, A.D. Global energy savings in offices buildings by the use of daylighting. Energy and Buildings, v.34, n.5, p. 421- 429, 2002. DOI:https://doi.org/10.1016/S0378-7788(01)00117-7.

BRAGER, G. S.; RING, E.; POWELL, K. Mixed-mode ventilation: HVAC meets Mother Nature. Engineered Systems, v.17, n.5, p. 60-70, 2000.

BRAGER, G. S. Mixed-mode cooling. ASHRAE journal, v. 48, n. 8, p. 30, 2006.

BRUGNERA, R. R.; RORIZ, V. F.; CHVATAL, K. M. S. Temperaturas de acionamento de condicionadores de ar e ventiladores. In: ENCONTRO NACIONAL DE CONFORTO NO AMBIENTE CONSTRUÍDO, 12. ENCONTRO LATINOAMERICANO DE CONFORTO NO AMBIENTE CONSTRUÍDO, 8., 2013, Brasília. Anais [...], Brasília, 2013.

BRUGNERA, R. R. Potencial de Economia de Energia em Edifícios de Escritórios Com Estratégias de Ventilação Híbrida. São Carlos, 2014. 76 f. Dissertação (Mestrado em Engenharia Civil) - Instituto de Arquitetura e Urbanismo, Universidade de São Paulo, São Carlos, 2014.

MASHALY, I. A.; RASHED, Y. M.; ADEL, M.; NASSAR, K. A new climate-based daylight metric for hot climates. In: BUILDING SIMULATION APPLICATIONS BSA CONFERENCE-ITALY, 2..,2015, Bozen-Bolzano. Proceedings [...], BozenBolzano:IBPSA-Italy, 2015. p. 155-162. Disponível em: http://www.ibpsa.org/?page id=681. Acesso em: 25.04.2019.

BREMBILLA, E.; HOPFE, C. J.; MARDALJEVIC, J. Influence of input reflectance values on climate-based daylight metrics using sensitivity analysis. Journal of Building Performance Simulation, v.1, n.3, p. 333-349, 2018. DOI:https://doi.org/10.1080/19401493.2017.1364786.

BURTON, S. Energy Efficient office refurbishment: Designing for Comfort. New York: Earthscan. ISBN: 978$1902916019,2013$.

CANTIN, F.; DUBOIS, M-C. Daylighting metrics based on illuminance, distribution, glare and directivity. Lighting Research \& Technology, v. 43, n. 3, p. 291-307, 2011. https://doi.org/10.1177/1477153510393319.

CARRIÈRES, K. R. M. Desempenho Térmico e Consumo Energético de Edifícios de Escritórios em São Carlos, SP. Dissertação (Mestrado em Engenharia Civil) - Faculdade de Engenharia Civil, Arquitetura e Urbanismo, Universidade Estadual de Campinas, Campinas, SP, 2007.

CASATEJADA, M. P.; CHVATAL, K. M. S. Comparação entre os horários habituais e recomendados de abertura tanto de janelas quanto de portas internas em habitações brasileiras. In: ENCONTRO NACIONAL DE CONFORTO NO AMBIENTE CONSTRUÍDO. 14., 2017. Anais [...]. Porto Alegre: ANTAC, 2017.

CBE, CENTER FOR THE BUILDING ENVIRONMENT. About Mixed Mode. University of California, Berkeley. Available at: https://www.cbe.berkeley.edu/mixedmode/aboutmm.html. Accessed in: oct 6, 2018.

CEPAGRI. Clima dos municípios paulistas. Campinas: Centro de Pesquisas Meteorológicas e Climáticas Aplicadas a Agricultura. Available at: http://www.cpa.unicamp.br/outras-informacoes/clima-dos-municipios-paulistas. [Accessed jul 6, 2016]. 
DALLA MORA, T.; LEORIN, A.; NARDO, G.; BUSATTO, N.; PERON, F.; ROMAGNONI, P. Daylight Performances in Typical Inner Spaces with Climate-Based Daylight Modeling Approach. In: BUILDING SIMULATION AND OPTIMIZATION CONFERENCE, 4., 2018, Cambridge. Proceedings [... ]. Cambridge: IBPSA-England, 2018. p. 11-12.

DIDONÉ, E. L.; PEREIRA, F. O. R. Simulação computacional integrada para a consideração da luz natural na avaliação do desempenho energético de edificações. Ambiente Construído, v. 10, n. 4, p. 139-154, 2010.

DORNELLES, K. A. Absortância solar de superfícies opacas: métodos de determinação e base de dados para tintas látex acrílica e PVA. PhD diss., Universidade Estadual de Campinas, 2008.

DRAKE, S.; DE DEAR, R.; ALESSI, A.; DEUBLE, M. Occupant comfort in naturally ventilated and mixed-mode spaces within air-conditioned offices. Architectural Science Review, v.53, n.3, p. 297-306, 2010.

DOI:https://doi.org/10.3763/asre.2010.0021.

DUBOIS. M. C.; BLOMSTERBERG, A. Energy saving potential and strategies for electric lighting in future North European, low energy office buildings: A literature review. Energy and Buildings, v. 43, n. 10, p. $2572-2582$, 2011. DOI:https://doi.org/10.1016/j.enbuild.2011.07.001.

DUBOIS, M. C.; FLODBERG, K. Daylight utilisation in perimeter office rooms at high latitudes: Investigation by computer simulation. Lighting Research and Technology. v. 45, p. 52-75, 2013. https://doi.org/10.1177/1477153511428918.

EERE - ENERGY EFFICIENCY RENEWABLE ENERGY. EnergyPlus. Version 8.o. US: Department of Energy Efficiency and Renewable Energy, Office of Building Technologies, 2012.

EERE - ENERGY EFFICIENCY RENEWABLE ENERGY. Input Output Reference: The Encyclopedic Reference to EnergyPlus Input and Output. US: Department of Energy Efficiency and Renewable Energy, Office of Building Technologies, 2013.

EZZELDIN, S.; REES, S. J.; COOK, M. Performance of mixed-mode cooling strategies for office buildings in arid climates. In: INTERNATIONAL CONFERENCE OF THE INTERNATIONAL BUILDING PERFORMANCE SIMULATION ASSOCIATION. 11., 2009, Glasgow. Proceedings [... ]. Scotland: IBPSA, 2009. p. 27-30.

EZZELDIN, S.; REES, S. J. The potential for office buildings with mixed-mode ventilation and low energy cooling systems in arid climates. Energy and Buildings, v.65, p.368-381, 2013.

DOI:https://doi.org/10.1016/j.enbuild.2013.06.004.

GHISI, E. The use of fibre optics on energy efficient lighting in buildings. PhD Thesis. School of Civil Engineering. University of Leeds. Leeds, UK, 2002.

GHISI, E.; TINKER, J A.; IBRAHIM, S. H. Área de janela e dimensões de ambientes para iluminação natural e eficiência energética: literatura versus simulação computacional. Ambiente Construído, v. 5, p. 81-93, 2005.

GOINS, J.; CHUN, C.; ZHANG, H. User perspectives on outdoor noise in open-plan offices with operable windows. Architectural Science Review, v. 56, n. 1, p. 42 - 47, 2013. DOI:https://doi.org/10.1080/00038628.2012.745390.

HEGAZY, M. A.; ATTIA, S.; MORO, J. L. Parametric analysis for daylight autonomy and energy consumption in hot climates. In: INTERNATIONAL CONFERENCE OF THE INTERNATIONAL BUILDING PERFORMANCE SIMULATION ASSOCIATION. 13., 2013, Chambery. Proceedings [... ]. Toronto: IBPSA, 2013. p. 2232-2240.

INMETRO - INSTITUTO NACIONAL DE METROLOGIA, NORMALIZAÇÃO E QUALIDADE INDUSTRIAL. RTQ-C: Regulamento Técnico da Qualidade para o Nível de Eficiência Energética de Edifícios Comerciais, de Serviços e Públicos. Rio de Janeiro, 2014.

INMETRO - INSTITUTO NACIONAL DE METROLOGIA, NORMALIZAÇÃO E QUALIDADE INDUSTRIAL. Condicionadores de ar split Hi-Wall. Available at: 
http://www.inmetro.gov.br/consumidor/pbe/condicionadores_ar_split_hiwall_indicenovo.pdf. [Accessed out 1, 2018].

JAKUBIEC, J. A.; REINHART, C. F. DIVA 2.0: Integrating Daylight and Thermal Simulations Using Rhinoceros 3D, Daysim and EnergyPlus. In: INTERNATIONAL CONFERENCE OF THE INTERNATIONAL BUILDING PERFORMANCE SIMULATION ASSOCIATION. 12., Sydeny. Proceedings [... ]. Toronto: IBPSA,2011, p. 2202-2209.

JI, Y.; LOMAS, K. J.; COOK, M, J. Hybrid ventilation for low energy building design in south China. Building and Environment, v.44, n.11, p. 2245-2255, 2009. DOl:https://doi.org/10.1016/j.buildenv.2009.02.015.

KARAVA, P.; ATHIENITIS, A.; STATHOPOULOS, K. T.; MOURIKI, E. Experimental Study of the Thermal Performance of a Large Institutional Building with Mixed-mode Cooling and Hybrid Ventilation. Building and Environment, v.57, p. 313-326, 2012.DOI: https://doi.org/10.1016/j.buildenv.2012.06.003.

MENDLER, S.; ODELL, W.; LAZARUS, M. A. The HOK Guidebook to Sustainable Design. Nova York: Wiley. ISBN: 978$0471696131,2006$.

NABIL, A.; MARDALJEVIC, J. Useful daylight illuminances: A replacement for daylight factors. Energy and Buildings, v. 38, n. 7, p. 905-913, 2006. DOl:https://doi.org/10.1016/j.enbuild.2006.03.013.

NRCC - NATIONAL RESEARCH COUNCIL CANADA. Daysim, Version 3.1. Harvard University. National Research Council Canada. Fraunhofer Institute for Solar Energy Systems, Germany, 2010.

RAIMONDI, A.; SANTUCCI, D.; BEVILACQUA, S.; CORSO, A. Daylight autonomy as a driver for office building retrofitting. Energy Procedia, v. 96, p. 180 - 189, 2016. DOl:https://doi.org/10.1016/j.egypro.2016.09.119.

RAMOS, G.; GHISI, E. Avaliação do cálculo da iluminação natural realizada pelo programa EnergyPlus. Ambiente Construído, v.10, n.2, p. 157-169, Apr./Jun, 2010.

REINHART, C.; FITZ, A. Findings from a survey on the current use of daylight simulations in building design. Energy and Buildings, v. 38, n. 7, p. 824-835, 2006. DOI:https://doi.org/10.1016/j.enbuild.2006.03.012.

REINHART, C. F.; WIENOLD, J. The daylighting dashboard - A simulation-based design analysis for daylit spaces. Building and Environment, v. 46, n.2, p. 386-396, 2011. https://doi.org/10.1016/j.buildenv.2010.08.001.

REINHART, C. F.; WEISSMAN, D. A. The daylit area - correlating architectural student assessments with current and emerging daylight availability metrics. Building Environment, v. 50, p. 155-164, April 2012.

DOI:https://doi.org/10.1016/j.buildenv.2011.10.024

RORIZ, M.; RORIZ, V. F. 2015. EPvieW software.

RORIZ, M. Arquivos climáticos de municípios brasileiros. ANTAC - Associação Nacional de Tecnologia do Ambiente Construído. Grupo de trabalho sobre Conforto e Eficiência Energética de Edificações. Relatório interno. Available at: http://www.labeee.ufsc.br/dowloads/arquivos-climaticos. Accessed in: out 9, 2012.

ROWE, D.; DINH, C. T. An Experiment with Hybrid Ventilation: A More Sustainable Approach to Thermal Comfort. Architectural Science Review, v. 44, n.2, p. 127-133, 2001. DOI: https://doi.org/10.1080/00038628.2001.9697462.

RUPP, R. F. Dimensionamento de Área de Janela em Edificações Comerciais: Integração da lluminação Natural com a Artificial e Utilização da Ventilação Híbrida. Dissertação (Mestrado em Engenharia Civil), Universidade Federal de Santa Catarina, Florianópolis, SC, 2011.

RUPP, R. F.; GHISI, E. Sizing window areas for daylighting and hybrid ventilation in commercial buildings. In: INTERNATIONAL CONFERENCE ON PASSIVE AND LOW ENERGY ARCHITECTURE. 28., 2012, Lima. Proceedings [... ]. Lima: PLEA, 2012. 
RUPP, Ricardo Forgiarini; GHISI, Enedir. Potencial de economia de energia elétrica em edificações comerciais híbridas localizadas em Florianópolis, SC. Ambient. constr., Porto Alegre, v. 13, n. 1, p. 143-160, Mar. 2013. DOI:http://dx.doi.org/10.1590/S1678-86212013000100010..

SALCIDO, J. C.; RAHEEM, A. A.; ISSA, R. R. A. From simulation to monitoring: Evaluating the potential of mixedmode ventilation (MMV) systems for integrating natural ventilation in office buildings through a comprehensive literature review. Energy and Buildings, v. 127, p. 1008-1018, 2016. DOI:https://doi.org/10.1016/j.enbuild.2016.06.054.

STABAT, P.; CACIOLO, M.; MARCHIO, D. Progress on single-sided ventilation techniques for buildings. Advances in Building Energy Research, v. 6, p. 212-241, 2012. DOI:https://doi.org/10.1080/17512549.2012.740903.

SUSOROVA, I.; TABIBZADEH, M.; RAHMAN, A.; CLACK, H. L.; ELNIMEIRI, M. The effect of geometry factors on fenestration energy performance and energy savings in office buildings. Energy and Buildings, v. 57, p. 6-13, 2013. DOI:https://doi.org/10.1016/j.enbuild.2012.10.035.

TABADKANI, A.; BANIHASHEMI, S.; HOSSEINI, M. R. Daylighting and visual comfort of oriental sun responsive skins: A parametric analysis. Building Simulation. Vol. 11, p. 663-676, 2018. DOI:https://doi.org/10.1007/s12273-018-0433-0.

WANG, L.; GREENBERG, S. Window operation and impacts on building energy consumption. Energy and Buildings, v. 92, p. 313-321, 2015.

YUN, G.; KIM, K. S. An empirical validation of lighting energy consumption using the integrated simulation method. Energy and Buildings, v. 57, p. 144-154, 2013. DOl:https://doi.org/10.1016/j.enbuild.2015.01.060.

YU, X.; SU, Y. Daylight availability assessment and its potential energy saving estimation - A literature review. Renewable and Sustainable Energy Reviews, v. 52, p. 494-503, 2015. DOI:https://doi.org/10.1016/j.rser.2015.07.142.

ZHOU, S.; LIU, D. Prediction of Daylighting and Energy Performance Using Artificial Neural Network and Support Vector Machine. American Journal of Civil Engineering and Architecture, v. 3, n. 3A, p. 1-8, 2015. DOI:https://doi.org/10.12691/ajcea-3-3A-1.

\section{${ }^{1}$ Rosilene Regolão Brugnera}

Arquiteta e Urbanista. Doutora em Ciências na área de Arquitetura, Urbanismo e Tecnologia pela Universidade de São Paulo (IAU-USP). Endereço postal: Avenida Trabalhador São-Carlense, 400 - Centro, São Carlos, SP, Brasil, CEP 13566-590

\section{${ }^{2}$ Caroline Antonelli Santesso}

Engenheira Ambiental. Mestre em Ciências na área de Arquitetura, Urbanismo e Tecnologia pela Universidade de São Paulo (IAU-USP). Endereço postal: Avenida Doutor Octávio da Silva Bastos, 2439, Jardim Nova São João, São João da Boa Vista, SP, Brasil, CEP 13874149

\section{Karin Maria Soares Chvatal}

Engenheira Civil. Doutora em Engenharia Civil pela Universidade do Porto. Professora Livre-Docente (Associada 1) do Instituto de Arquitetura e Urbanismo da Universidade de São Paulo (IAU-USP). Endereço postal: Avenida Trabalhador São-Carlense, 400 - Centro, São Carlos, SP, Brasil, CEP 13566-590 